Research Paper

\title{
Concentration, characterization and application of lipases from Sporidiobolus pararoseus strain
}

\author{
Alessandra Smaniotto ${ }^{1}$, Aline Skovronski ${ }^{1}$, Elisandra Rigo ${ }^{1}$, Siu Mui Tsai ${ }^{2}$, \\ Ademir Durrer ${ }^{2}$, Lillian Liva Foltran ${ }^{2}$, Natália Paroul ${ }^{1}$, Marco Di Luccio ${ }^{3}$, \\ J. Vladimir Oliveira ${ }^{3}$, Débora de Oliveira ${ }^{3}$, Helen Treichel $^{4}$ \\ ${ }^{1}$ Departamento de Engenharia de Alimentos, Universidade Regional Integrada do Alto Uruguai e das \\ Missões, Campus de Erechim, Erechim, RS, Brazil. \\ ${ }^{2}$ Laboratório de Biologia Celular e Molecular, Universidade de São Paulo, Piracicaba, SP, Brazil. \\ ${ }^{3}$ Departamento de Engenharia Química e de Alimentos, Universidade Federal de Santa Catarina, \\ Campus Universitário, Florianópolis, SC, Brazil. \\ ${ }^{4}$ Universidade Federal da Fronteira Sul, Campus de Erechim, Erechim, RS, Brazil.
}

Submitted: July 20, 2012; Approved: September 9, 2013.

\begin{abstract}
Lipases produced by a newly isolated Sporidiobolus pararoseus strain have potential catalytic ability for esterification reactions. After production, the enzymatic extracts (conventional crude and precipitated, 'CC' and 'CP', and industrial crude and precipitated, 'IC' e 'IP') were partially characterized. The enzymes presented, in general, higher specificity for short chain alcohols and fatty acids. The precipitated extract showed a good thermal stability, higher than that for crude enzymatic extracts. The ' $\mathrm{CC}$ ' and ' $\mathrm{CP}$ ' enzymes presented high activities after exposure to $\mathrm{pH} 6.5$ and $40{ }^{\circ} \mathrm{C}$. On the other hand, the 'IC' and 'IP' extracts kept their activities in a wide range of $\mathrm{pH}$ memory but presented preference for higher reaction temperatures. Preliminary studies of application of the crude lipase extract in the enzymatic production of geranyl propionate using geraniol and propionic acid as substrates in solvent-free system led to a reaction conversion of $42 \pm 1.5 \%$.
\end{abstract}

Key words: Sporidiobolus pararoseus, 'synthetic lipase', submerged fermentation, enzyme characterization.

\section{Introduction}

Lipases are ubiquitous in all types of living organisms and can be obtained from different sources such as microorganisms, animals and plants (Lotti and Alberguina, 2007; Bon et al., 2008; Reis et al., 2009). The enzymes of bacteria and fungi have the greatest potential as industrial biocatalysts, as they present high reaction rates, high-yield conversion of substrate to product, great versatility and simplicity in environmental and genetic manipulation of its productive capacity and easy recovery from fermentation broth (Lotti and Alberguina, 2007; Bon et al., 2008).

Microbial lipases are produced mainly by submerged culture (Sharma et al., 2001) and a wide variety of culture conditions that stimulate or suppress the production of mi- crobial lipases is described in the literature. However, there is no general procedure to improve lipase production (Kademi et al., 2004). The so-called 'industrial medium' for production of lipases commonly uses agroindustrial wastes or byproducts in its formulation, while the conventional medium is based on ingredients with a definite composition like salts, aminoacids, vitamins, growth factors, or costly complex ingredients like yeast extract, peptones and malt extract, among others. The main advantage of the industrial medium over the conventional one is its reduced costs, which may impact on the final product price. Over the recent years, research on the selection of suitable substrates for fermentative processes has mainly focused on agroindustrial residues, due to their potential advantages. Utili-

Send correspondence to H. Treichel. Universidade Federal da Fronteira Sul, Campus de Erechim, Erechim, RS, Brazil. E-mail: helentreichel@gmail.com. 
zation of agroindustrial wastes provides alternative substrates and may help solving pollution problems, which otherwise might be caused by their disposal. The choice of the substrate depends upon several factors, mainly related to cost and availability (Treichel et al., 2010).

After the fermentation step, the enzyme is contained in a medium together with a series of other compounds of no interest. Precipitation is normally used as the first step in the purification procedure and the ammonium sulfate fractionation is the method most widely used (Martins et al., 2008).

The effects of some variables on the activity of crude and purified lipases have been studied by some researchers. Factors such as $\mathrm{pH}$, temperature, metallic ions, organic solvents, among others, can increase or decrease lipase activity. Besides, lipases can present different specificity to substrates. So, biochemical characterization can determine the adequacy of each enzyme to industrial processes (Hasan et al., 2006).

Lipases that present esterification activity are gaining more attention nowadays because of their potential to catalyze the production of biodiesel, bioaromas and pharmaceuticals, reducing the operational costs associated with the conventional process, as well as overcoming problems related with chemical catalysis. As the production cost of the lipase is a major obstacle to the commercialization of the enzyme catalyzed process, various attempts have been made to develop cheaper systems. Many other applications of lipase with synthetic activity have been proposed, such as enantioselective reactions, synthesis of various esters and kinetic resolutions of chiral compounds (Treichel et al., 2010).

In this context, this work aimed at characterization of crude and precipitated lipase extracts from conventional and industrial media in terms of stability at high and low temperatures, esterification substrate specificity (different fatty acids and alcohols) and acting ranges of memory of $\mathrm{pH}$ and temperature. A preliminary investigation of the potential application of the crude lipase extract on the enzymatic production of geranyl propionate using geraniol and propionic acid as substrates in solvent-free system was also carried out.

\section{Materials and Methods}

\section{Cell production}

The yeast used in the present study was previously isolated from soybean meal (9) and identified as Sporidiobolus pararoseus (Smaniotto et al., 2012). It was maintained in glycerol at $-80{ }^{\circ} \mathrm{C}$ and potato dextrose agar slants under refrigeration. The propagation was carried out for 3 days at $30^{\circ} \mathrm{C}$ in Petri dishes containing a medium constituted by potato dextrose agar (PDA) $3.9 \mathrm{wt} \%$ and distilled water. The pre-inoculum was prepared by transferring the microorganism from the Petris dish to test tubes containing $10 \mathrm{~mL}$ of $\mathrm{PC}$ medium $(0.5,0.25$ and 0.1 $\mathrm{wt} \%$ of tryptone, yeast extract and dextrose, respectively) sterilized at $121{ }^{\circ} \mathrm{C}$ for $15 \mathrm{~min}$. The mixture was incubated at $30^{\circ} \mathrm{C}$ for $24 \mathrm{~h}$. The inoculum was prepared by mixing the pre-inoculum with $90 \mathrm{~mL}$ of sterilized $\mathrm{PC}$ medium in $250 \mathrm{~mL}$ Erlenmeyer flasks covered with cotton plugs. Flasks were incubated in a rotary shaker at $30{ }^{\circ} \mathrm{C}$ and 150 for $24 \mathrm{~h}$.

\section{Culture conditions}

Lipase was produced in conventional and industrial media. The conventional medium consisted of 5.0, 6.8, 7.0 and $1.0 \mathrm{wt} \%$ of peptone, yeast extract, $\mathrm{NaCl}$ and olive oil, respectively. The industrial medium consisted of corn steep liquor $(5.0 \mathrm{wt} \%)$, hydrolyzed yeast extract $(6.8 \mathrm{wt} \%)$, waste frying oil $(1.0 \mathrm{wt} \%)$ and $\mathrm{NaCl}(7.0 \mathrm{wt} \%)$. Residual frying oil consisted of refined soybean oil, submitted to three successive frying batches of potatos at $180^{\circ} \mathrm{C}$ (Juaréz et al., 2011). Cultivation was carried out in $250 \mathrm{~mL}$ Erlenmeyer flasks covered with cotton plugs in rotary shaker at $30^{\circ} \mathrm{C}$ and $150 \mathrm{rpm}$. The media (in $90 \mathrm{~mL}$ aliquots) were sterilized at $121{ }^{\circ} \mathrm{C}$ for $15 \mathrm{~min}$, cooled and inoculated with the inoculum solution $(10 \%)$. After fermentation, samples were collected and filtered through Whatmann qualitative paper. The filtrate was frozen at $-80{ }^{\circ} \mathrm{C}$ for $24 \mathrm{~h}$ and then lyophilized for $48 \mathrm{~h}$. The resultant solid was considered as the crude enzymatic extract and used for analytical assays.

\section{Concentration of crude enzymatic extract}

Ammonium sulfate was added to $150 \mathrm{~mL}$ of extract until the desired degree of saturation. The precipitation was carried out in single steps (using 40 and $60 \%$ of the saturation concentration) and in two sequential steps. The first step was carried out with addition of ammonium sulfate until $20 \%$ of saturation was reached. After the separation of the precipitated material, the supernatant was then further precipitated adding ammonium sulfate up to $40 \%$ of saturation.

The mixture was kept at $4{ }^{\circ} \mathrm{C}$ in an ice bath with constant agitation, with the $\mathrm{pH}$ maintained at 7.0 through the addition of $\mathrm{NaOH} 20 \%$. The mixture was then transferred to centrifuge tubes, maintained at $-10^{\circ} \mathrm{C}$ for $5 \mathrm{~h}$ and then centrifuged at $4{ }^{\circ} \mathrm{C}$ and $5400 \mathrm{~g}$ for $30 \mathrm{~min}$. The supernatant was discarded and the precipitate removed with a minimum amount of sodium phosphate buffer $100 \mathrm{mM} \mathrm{pH} 7.0(8,10)$. Samples were freezed at $-80^{\circ} \mathrm{C}$ and lyophilized for $48 \mathrm{~h}$. The enzymes obtained in conventional and in industrial media in the crude (CC and IC) and precipitated (CP and IP) forms were partially characterized as described below. Protein was determined in all extracts as described by Fernandes et al. (2004).

\section{Esterification activity}

Lipase synthetic activity was assayed by alkali titration using oleic acid and ethanol as substrates. An amount 
of $0.1 \mathrm{~g}$ sample of lyophilized enzyme was added to a 1:2 mixture of oleic acid and ethanol. After incubation in shaker for $40 \mathrm{~min}$ at $40^{\circ} \mathrm{C}$ and $150 \mathrm{rpm}$, the reaction was interrupted and the products were extracted by the addition of $20 \mathrm{~mL}$ of an acetone/ethanol solution $(1: 1 \mathrm{v} / \mathrm{v})$. The residual oleic acid was titrated with $0.02 \mathrm{M} \mathrm{NaOH}$ until pH 11. Reaction blanks were run in the same way, but adding the sample after addition of acetone/ethanol solution. The assays were carried out in duplicates. A unit of lipase activity was defined as the amount of enzyme that consumes $1 \mu \mathrm{mol}$ of oleic acid per minute under the assay conditions.

\section{Specificity of the crude and precipitated enzymatic extract}

The crude and precipitated lyophilized enzymatic extracts were characterized based on their esterification activity in different alcohols (methanol, ethanol, n-propanol and n-butanol) and fatty acids (lauric (12:0), oleic (18:1) and butyric (4:0)) $(4,5,31)$.

\section{Stability of the crude and precipitated enzymatic extract at low and high temperatures}

The stability of lyophilized crude and precipitated enzymatic extracts at low temperatures was studied at 4 and $-10^{\circ} \mathrm{C}$ by measuring the esterification activities each 5 days during storage. The evaluation of stability at high temperatures was carried out by incubation at 30,45 and $60^{\circ} \mathrm{C}$. The esterification activity was monitored every $24 \mathrm{~h}$ until total loss of activity.

\section{Effect of temperature and $\mathrm{pH}$ memory on the crude and precipitated extracts}

The $\mathrm{pH}$ memory was assessed by incubating the crude and precipitated enzymes ('CC', 'CP', 'IC' and 'IP') in different buffers ( $\mathrm{pH}$ varying from 3.0 to 10.0) for $20 \mathrm{~min}$ at $4{ }^{\circ} \mathrm{C}$. The extracts were then lyophilized, according to Sun et al. (2009) and the esterification activity was measured at different temperatures $\left(11.8-68.2^{\circ} \mathrm{C}\right)$ following the method described below.

These ranges of $\mathrm{pH}$ and temperature were evaluated according to a composite central rotatable design (DCCR) $2^{2}$, which was carried out for each extract.

\section{Enzymatic esterification for production of geranyl esters}

The esterification reactions were carried out by preparing a reactional mixture of geraniol, propionic acid (at molar ratios optimized previously by our research group using commercial lipases) and molecular sieves $(20 \mathrm{mg} / \mathrm{mL}$ of substrates) in a $50 \mathrm{~mL}$ Erlenmeyer. After complete dissolution of the substrates, the enzymatic extract was added to the mixture. All experiments were carried out in an orbital shaker at constant agitation of $150 \mathrm{rpm}$. After the reaction time completion, the samples were kept at $5{ }^{\circ} \mathrm{C}$ for further determination of reaction conversion, following a previously established method (Sun and Xu, 2008).

Quantitative analyses of geranyl esters produced were carried out in a gas chromatograph (Shimadzu GC2010), using a capillar column of fused silica INOWAX (30 m length $\times 250 \mu \mathrm{m}$ i.d. $\times 0.25 \mu \mathrm{m}$ thickness), flame ionization detector, with the following temperature program: $40-180{ }^{\circ} \mathrm{C}\left(3{ }^{\circ} \mathrm{C} / \mathrm{min}\right), 180-230{ }^{\circ} \mathrm{C}\left(20^{\circ} \mathrm{C} / \mathrm{min}\right), 230^{\circ} \mathrm{C}$ (20 min), injector temperature $250^{\circ} \mathrm{C}$, detector at $275^{\circ} \mathrm{C}$, injection in the mode split, ratio of split 1:100. Hydrogen $(56 \mathrm{KPa}$ ) was used as carrier gas and a volume of $0.4 \mu \mathrm{L}$ of sample diluted in $n$-hexane $(1: 10)$ was injected. Reaction conversion was calculated based on the reduction of area of limitant reagent on the basis of reaction stoichiometry (Sun and $\mathrm{Xu}, 2008$ ).

\section{Results and Discussion}

\section{Lipase production}

The yeast Sporodiobolus pararoseus isolated and identified by our research group was previously presented as good synthetic lipase producer. Using the conventional optimized medium as substrate (Smaniotto et al., 2012) the esterification activity was $26.9 \mathrm{U} / \mathrm{mL}$ of fermented medium in $72 \mathrm{~h}$ of fermentation. This yield is higher than those reported in literature for good lipase producer strains. Teng and $\mathrm{Xu}$ (Teng and $\mathrm{Xu}, 2008$ ) obtained $13.9 \mathrm{U} / \mathrm{mL}$ of a lipase produced by Rhizopus chinensis at optimal conditions.

In the present study, the Sporodiobolus pararoseus was used to produce lipase using a low-cost substrate based on corn steep liquor, hydrolyzed yeast extract, waste frying oil and $\mathrm{NaCl}$. The crude enzymatic extract obtained after $72 \mathrm{~h}$ of fermentation presented $12.3 \mathrm{U} / \mathrm{mL}$ of esterification activity. Although the lipase activity with this medium was lower than that obtained from conventional one, the lower costs of the residues may justify the study of the precipitation and characterization of the enzyme extract from industrial media.

It is important to mention that the corn steep liquor and the yeast hydrolysate presents a complex composition and both are sources of nitrogen, carbon, mineral salts and vitamins. The industrial medium contains a rich mixture of nutrients that might repress lipase production (Wang et al., 2008). Pinheiro et al. (2008), studying the conventional and industrial media for lipase production by submerged fermentation from Penicillium verrucosum, observed that the lipase hydrolytic activity was 1.2 times higher in the conventional compared to the industrial medium. Immanuel et al. (2008) also discuss the importance of the use of industrial medium for enzyme production. They evaluated the substitution of the tryptone by casein in the production of an extracellular lipase from Serratia rubidaea, which caused an increase from 4.0 to $6.5 \mathrm{U} / \mathrm{mL}$. Bapiraju et al. (2005), in an optimization study of lipase production by a 
mutant Rhizopus sp., concluded that the potato starch, corn steep liquor and olive oil were the most promising sources of carbon, nitrogen and lipids, respectively.

\section{Concentration of the crude enzymatic extracts}

Table 1 presents the results obtained for the concentration using ammonium sulfate in terms of esterification activity (U/g lyophilized extract), protein content $(\mathrm{mg} / \mathrm{mL})$ and specific esterification activity $\left(\mathrm{U} / \mathrm{mg}_{\text {protein }}\right)$. The first step of the fractional precipitation $(20 \%$ of ammonium sulfate saturation) resulted in higher purification folds for the lipase produced both in conventional and industrial media (1.2 and 0.5 -fold, respectively). These precipitated extracts presented the highest synthesis activity (154.6 and $120.9 \mathrm{U} / \mathrm{g}$ lyophilized extract, respectively) and the lowest protein content.

Specific lipase activity and purification folds presented in the literature vary a lot according to fermentation and precipitation condition, as well as the microorganism. The literature points out that the purification folds by precipitation with ammonium sulfate are usually low, but can reach up to 10 , when optimized conditions are applied (Bradoo et al., 2002; Stanburry et al., 2003; Bapiraju et al., 2005; Bon et al., 2008).

\section{Characterization of the lipases}

\section{Specificity of the crude and precipitated enzymatic extracts}

The esterification activity of the crude extracts using butyric and oleic acids as substrates and different alcohols is presented in Figure 1 (a) and (b), respectively. In general, the use of butyric acid as acil donor affords higher esterification activities. The IC extract presented the highest esterification activity using methanol, independent from the acid used.

It is interestig to note that higher specificities for methanol and butanol can be observed when butyric acid is used. The same behavior can be seen using oleic acid when the enzymes from industrial medium (IC and IP) were evaluated. The alcohol specificity, towards oleic acid esterification, of the lipase produced with conventional medium presented a distinct behavior from that described above, since higher activities were obtained using methanol, ethanol and propanol with the enzymes $\mathrm{CC}$ and $\mathrm{CP}$, respectively. When lauric acid was used as the acil donor, only the enzymes from the industrial medium (IC and IP) presented esterification activities, using methanol as substrate.

The produced enzymes showed higher apparent specificities for short chain fatty acids (butyric acid) and short chain alcohols (methanol). Sun et al. (2009) and Wang et al. (1995) cite that lipases commonly present higher specificity to fatty acids with 8 to 16 carbons. Usually, short chain fatty acids are known as inhibitors of the catalytic activity of the lipases. However, Abbas and Comeau (2003) showed that a lipase from Mucor sp. was able to catalyze esterification reaction using different alcohols and acids.

The lipase evaluated by Abbas and Comeau (2003) presented a particular specificity to short chains alcohols such as methanol, ethanol, 2-propen-1-ol and butanol. These results are in agreement with the studies carried out by Langrand et al. (1998) and Sun et al. (2009), where the yields decreased with the increase of the number of carbons. According to Ghandi et al. (1995) and Abbas and Comeau (2003) differences in lipase specificities to different alcohols can be explained in terms of the binding energy that is liberated when the substrate binds to the active site.

Table 1 - Concentration of lipase extract using ammonium sulfate.

\begin{tabular}{lllll}
\hline Extract ${ }^{\mathrm{a}}$ & $\begin{array}{c}\text { Esterification activity } \\
\left(\mathrm{U} / \mathrm{g}_{\text {lyophilized extract }}\right)\end{array}$ & $\begin{array}{c}\text { Protein content } \\
\left(\mathrm{mg} / \mathrm{g}_{\text {lyophilized extract }}\right)\end{array}$ & $\begin{array}{c}\text { Specific esterification } \\
\text { activity }\left(\mathrm{U} / \mathrm{mg}_{\text {protein }}\right)\end{array}$ & Purification factor \\
\hline $\begin{array}{l}\text { Conventional } \\
\text { Crude }\end{array}$ & 127.31 & 0.26 & 489.65 & 1 \\
D40 & 115.69 & 4.12 & 28.07 & 0.06 \\
D60 & 119.31 & 3.76 & 31.74 & 0.06 \\
F20 & 154.57 & 0.26 & 594.5 & 1.21 \\
F40 & 103.10 & 1.03 & 100.09 & 0.20 \\
Industrial & & & & 1 \\
Crude & 58.31 & 0.11 & 530.10 & 0.07 \\
D40 & 86.65 & 2.33 & 37.18 & 0.05 \\
D60 & 77.56 & 3.02 & 25.68 & 0.52 \\
F20 & 120.96 & 0.44 & 274.91 & 0.08 \\
F40 & 95.63 & 2.20 & 43.47 & \\
\hline
\end{tabular}

${ }^{a}$ D40 and D60 refer to the extract precipitated by direct addition of ammonium sulfate at $40 \%$ and $60 \%$ of saturation. F20 and F40 refer to the extracts obtained by fractional precipitation in the first and second steps, respectively. 

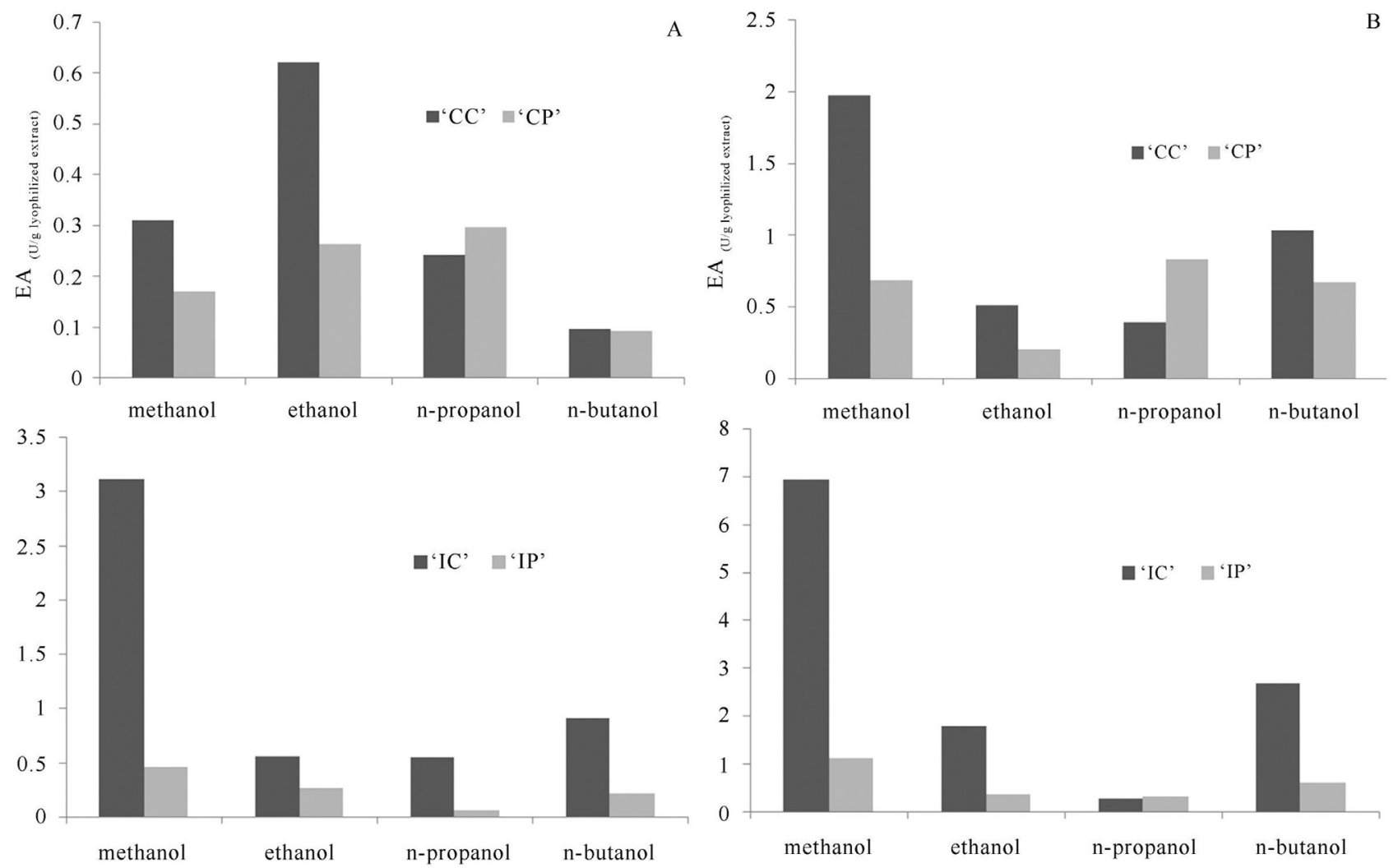

Figure 1 - Esterification activities (EA) of the crude extracts using oleic (a) and butyric (b) acids as substrates and different alcohols.

Short chain ethyl esters synthesized from acids are an important group of flavor and fragrances widely employed in food and beverages' industries (Kashmiri et al., 2006). The market value of such compounds obtained by enzymatic reactions is usually higher than those produced by the conventional chemical path. Few studies can be found in the literature showing the specificity of non-commercial lipases to short-chain substrates, since these compounds can cause inhibitory effects (Peter and Preda; 2002; Shu et al., 2006). So, the lipases presented here can find potential application in the production of flavours.

\section{Stability of the crude and precipitated enzymatic extracts to low and high temperatures}

Figures 2, 3 and 4 present the evolution of lipase activities with time of incubation at 30,45 and $60^{\circ} \mathrm{C}$, respectively. From Fig. 2 it is possible to observe the activation of the enzymes when incubated at $30^{\circ} \mathrm{C}$. The enzymes from conventional medium presented a maximum esterification activity after $20 \mathrm{~h}$ of incubation, at this time an increase of 5.3 and 3.4-fold in the activity was observed for the $\mathrm{CC}$ and $\mathrm{CP}$, respectively. The extracts IC and IP showed the highest esterification activity after 92 and $20 \mathrm{~h}$ of incubation ( 2.8 and 1.3 times), respectively. The crude extracts presented a more marked activation. However, after $160 \mathrm{~h}$ of incubation, almost complete deactivation of all the extracts occurred. The activation of lipases at $30^{\circ} \mathrm{C}$ was also observed by Fernandes et al. (2004) studying hydrolysis reactions catalyzed by lipases from Thermomyces lanuginosa.

Figure 3 shows that at $45^{\circ} \mathrm{C}$ the enzyme IP did not present an initial activation, but this extract kept the enzyme activity until $116 \mathrm{~h}$ of incubation. At $60^{\circ} \mathrm{C}$ (Figure 4), all extracts lost the esterification activity during the incubation time ( $92 \mathrm{~h}$ ) and the $\mathrm{CC}$ was the most heat sensitive (loss of all activity after $44 \mathrm{~h}$ of incubation).

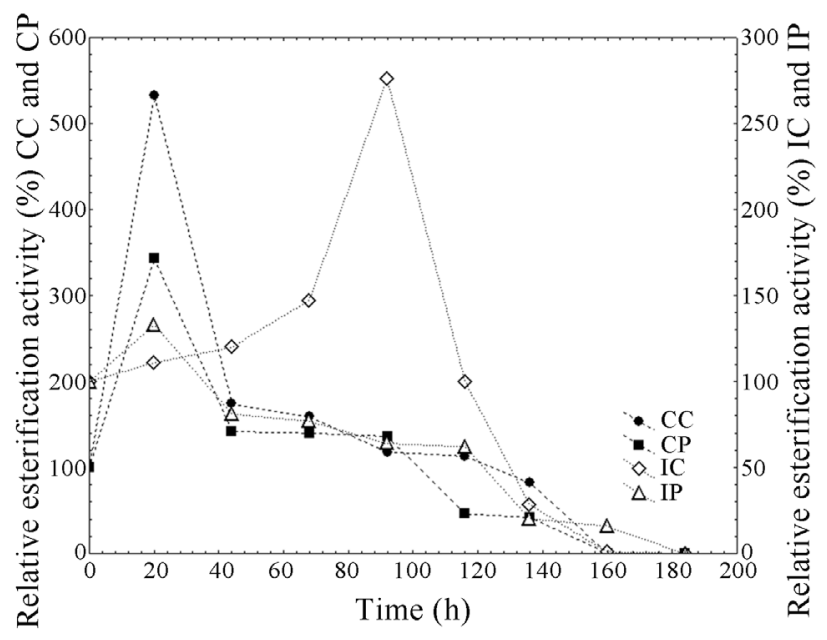

Figure 2 - Lipase activities during incubation at $30{ }^{\circ} \mathrm{C}$. Initial activities: $\mathrm{CC}=127.3 \mathrm{U} / \mathrm{g}, \mathrm{CP}=154.6 \mathrm{U} / \mathrm{g}, \mathrm{IC}=58.3 \mathrm{U} / \mathrm{g}, \mathrm{IP}=121.0 \mathrm{U} / \mathrm{g}$. 


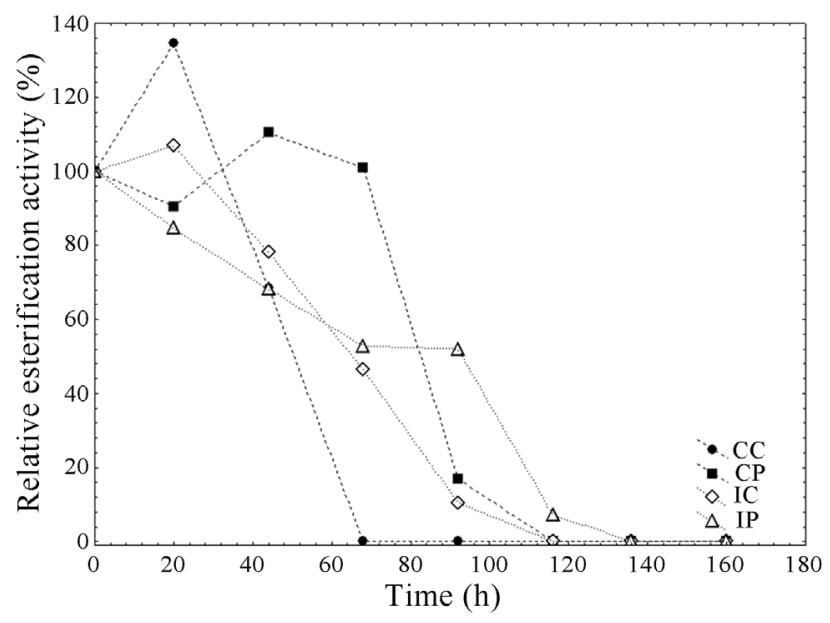

Figure 3 - Lipase activities during incubation at $45{ }^{\circ} \mathrm{C}$. Initial activities: $\mathrm{CC}=127.3 \mathrm{U} / \mathrm{g}, \mathrm{CP}=154.6 \mathrm{U} / \mathrm{g}, \mathrm{IC}=58.3 \mathrm{U} / \mathrm{g}, \mathrm{IP}=121.0 \mathrm{U} / \mathrm{g}$.

The evaluation of low temperature stability showed that the precipitated enzymes $\mathrm{CP}$ and IP presented higher stabilities. Both kept $100 \%$ of their esterification activity until 60 days of storage at 4 and $-10{ }^{\circ} \mathrm{C}$. These results are in agreement with the work of Menoncin et al. (2010). The study of these authors showed that a concentrated lipase extract from Penicillium verrucosum kept its activity until 90 days of storage at the same low temperatures. Thus, the precipitation step is advantageous when considering the lipase stability. Although the esterification activity did not improve when the extracts were precipitated, the increase in the stability could be considered a promising result in terms of future application of these extracts.

\section{Effect of temperature and memory of $\mathrm{pH}$ on the crude and precipitated extracts}

According to Sun et al. (2009) and Sun and Xu (2008), lyophilized enzymes present a "memory of $\mathrm{pH}$ " ef-

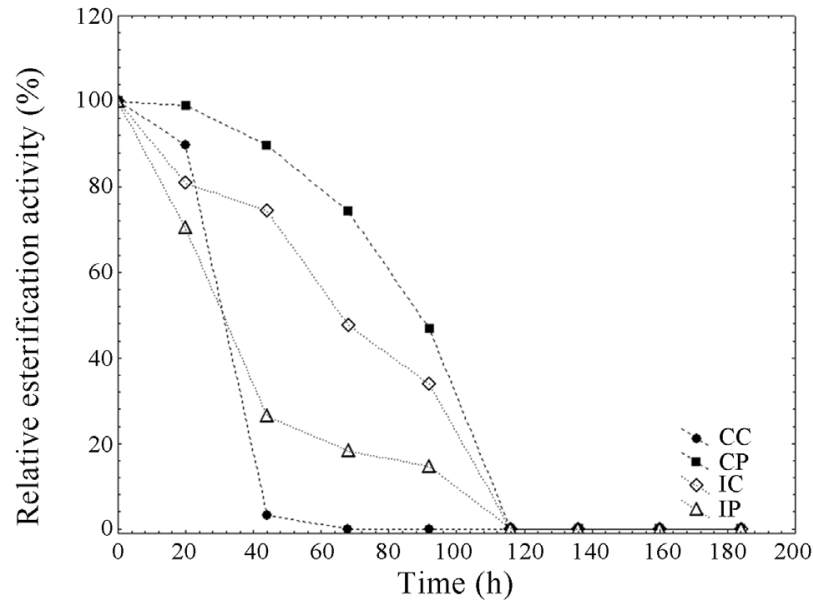

Figure 4 - Lipase activities during incubation at $60^{\circ} \mathrm{C}$. Initial activities: $\mathrm{CC}=127.3 \mathrm{U} / \mathrm{g}, \mathrm{CP}=154.6 \mathrm{U} / \mathrm{g}, \mathrm{IC}=58.3 \mathrm{U} / \mathrm{g}, \mathrm{IP}=121.0 \mathrm{U} / \mathrm{g}$.

fect. This can be explained by the fact that the esterification activity in organic solvents is extremely dependent on the $\mathrm{pH}$ of the aqueous solution before the lyophilization. This "memory of $\mathrm{pH}$ " effect probably occurs due to the ionic fixation of the catalytic site. Thus, after freeze-drying of the enzyme, the biocatalyst keeps the same state as in non-aqueous medium.

To evaluate the behavior of the extracts at different temperatures and $\mathrm{pH}$ memories, one CCRD $2^{2}$ was carried out for each extract. Table 2 presents the matrix of the experimental design and the respective responses in terms of esterification activity for each extract.

The highest activity was obtained for the $\mathrm{CC}$ extract

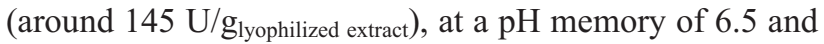
$40{ }^{\circ} \mathrm{C}$. High activity values for the $\mathrm{CP}$ were obtained at the central points (around de $64 \mathrm{U} / \mathrm{g}_{\text {lyophilized extract), and these }}$ values show that the enzymes from conventional medium

Table 2 - Effect of the temperature and $\mathrm{pH}$ memory on the crude and precipitated extract: Matrix of the experimental design (coded and real values) and the respective responses in terms of esterification activity for each extract.

\begin{tabular}{|c|c|c|c|c|c|c|}
\hline \multirow[t]{2}{*}{ Run } & \multirow[t]{2}{*}{$\mathrm{pH}$} & \multirow[t]{2}{*}{$\mathrm{T}\left({ }^{\circ} \mathrm{C}\right)$} & \multicolumn{4}{|c|}{ Esterification activity (U/g $\left.\mathrm{g}_{\text {lyophilized extract }}\right)$} \\
\hline & & & $\mathrm{CC}$ & $\mathrm{CP}$ & $\mathrm{IC}$ & IP \\
\hline 1 & $-1(4.0)$ & $-1(20)$ & 26.87 & 4.65 & 18.42 & 9.09 \\
\hline 2 & $+1(9.0)$ & $-1(20)$ & 22.54 & 4.61 & 32.56 & 0.00 \\
\hline 3 & $-1(4.0)$ & $+1(60)$ & 52.55 & 8.96 & 92.41 & 50.96 \\
\hline 4 & $+1(9.0)$ & $+1(60)$ & 114.51 & 42.47 & 39.92 & 42.80 \\
\hline 5 & $0(6.5)$ & $0(40)$ & 143.57 & 64.78 & 32.90 & 8.52 \\
\hline 6 & $0(6.5)$ & $0(40)$ & 159.20 & 59.86 & 38.10 & 9.26 \\
\hline 7 & $0(6.5)$ & $0(40)$ & 132.44 & 66.66 & 44.21 & 8.44 \\
\hline 8 & $0(6.5)$ & $-1.41(11.8)$ & 0.00 & 0.00 & 0.00 & 0.00 \\
\hline 9 & $0(6.5)$ & $+1.41(68.2)$ & 0.00 & 0.00 & 85.9 & 48.46 \\
\hline 10 & $-1.41(3.0)$ & $0(40)$ & 56.62 & 52.54 & 0.00 & 0.00 \\
\hline 11 & $+1.41(10.0)$ & $0(40)$ & 7.44 & 0.00 & 0.00 & 0.00 \\
\hline
\end{tabular}


presented higher activities at $\mathrm{pH}$ memory of about 7 and near ambient temperatures.

High activities were also obtained with lipase produced with industrial medium, in runs $3\left(\mathrm{pH} 4.0\right.$ and $60^{\circ} \mathrm{C}$ ) and $9\left(\mathrm{pH} 6.5\right.$ and $\left.68.2^{\circ} \mathrm{C}\right)$, showing that the enzymes present activity in a wide range of $\mathrm{pH}$ memory and high temperatures.

Table 3 presents the empirical models that predict the lipase activity as a function of $\mathrm{pH}$ and temperature. All of them were validated $\left(\mathrm{F}_{\text {calculated }}>\mathrm{F}_{\text {listed }}\right)$ by analysis of variance (Table 4) at $90 \%$ of confidence level. The determination coefficients were $81,80,85$ and $90 \%$ for the extracts $\mathrm{CC}, \mathrm{CP}, \mathrm{IC}$ and IP, respectively.

\section{Preliminary studies for the application of the lipase extract}

Preliminary studies of application of the conventional crude lipase extract in the enzymatic production of geranyl propionate using geraniol and propionic acid as substrates, in solvent-free system, showed that in optimized operating conditions for propionate production using commercial lipases (geraniol to propionic acid molar ratio of $3: 1,40^{\circ} \mathrm{C}$, $150 \mathrm{rpm}$ and $10 \mathrm{wt} \%$ of enzyme, conversions of about $95 \%$ (Sun and $\mathrm{Xu}, 2008$ )), a reaction conversion of $42 \pm 1.5 \%$ was achieved. This result is very promising, since it was obtained using optimized conditions for a commercial lipase. Probably, after optimization of operation parameters for the lipase of Sporidiobolus pararoseus, higher conversions could be obtained.

\section{Conclusions}

The yeast Sporodiobolus pararoseus is a promising synthetic lipase producer using conventional $(13.9 \mathrm{U} / \mathrm{mL})$ and industrial $(12.3 \mathrm{U} / \mathrm{mL})$ media. The enzymatic extracts presented, in general, higher specificity for short chain al-

Table 3 - Empiric models for the esterification activity in function of $\mathrm{pH}$ and temperature for each studied extract.

\begin{tabular}{ll}
\hline Extract & Coded model \\
\hline $\mathrm{CC}$ & $144.92-1.47 p H(L)-47.00 p H(Q)+14.75 T(L)-63.12 T(Q)+16.57 p H(L) T(L)$ \\
$\mathrm{CP}$ & $63.75-5.09 p H(L)-18.27 p H(Q)+5.29 T(L)-31.48 T(Q)+8.39 p H(L) T(L)$ \\
$\mathrm{IC}$ & $153.27-12.87 p H(L)+99.38 T(L)-19.84 p H(L) T(L)$ \\
$\mathrm{IP}$ & $8.69-2.16 p H(L)-0.96 p H(Q)+10.18 T(L)+11.23 T(Q)+0.23 p H(L) T(L)$ \\
\hline
\end{tabular}

Table 4 - Analysis of variance for each model presented in Table 3.

\begin{tabular}{|c|c|c|c|c|c|}
\hline Extract & & Sum of squares & Degress of freedom & Mean of squares & F calculated \\
\hline \multirow[t]{5}{*}{$\mathrm{CC}$} & Regression & $30,178.05$ & 5 & $6,035.61$ & 4.24 \\
\hline & Residues & $7,113.31$ & 5 & $1,422.661$ & \\
\hline & Lack of fit & 361.42 & 3 & & \\
\hline & Pure Error & $6,751.88$ & 2 & & \\
\hline & Total & $37,291.36$ & 10 & & \\
\hline \multirow[t]{5}{*}{$\mathrm{CP}$} & Regression & $6,768.35$ & 5 & $1,353.67$ & 3.96 \\
\hline & Residues & $1,710.69$ & 5 & 342.14 & \\
\hline & Lack of fit & 24.66 & 3 & & \\
\hline & Pure Error & 1686.03 & 2 & & \\
\hline & Total & 8479.04 & 10 & & \\
\hline \multirow[t]{5}{*}{ IC } & Regression & $42,119.73$ & 3 & $14,039.91$ & 5.73 \\
\hline & Residues & $7,356.25$ & 3 & $2,452.08$ & \\
\hline & Lack of fit & 64.10 & 2 & & \\
\hline & Pure Error & $7,292.16$ & 1 & & \\
\hline & Total & $49,475.98$ & 6 & & \\
\hline \multirow[t]{5}{*}{ IP } & Regression & $3,788.41$ & 5 & 757.68 & 8.70 \\
\hline & Residues & 435.61 & 5 & 87.12 & \\
\hline & Lack of fit & 0.41 & 3 & & \\
\hline & Pure Error & 435.20 & 2 & & \\
\hline & Total & $4,224.01$ & 10 & & \\
\hline
\end{tabular}

$\mathrm{F}_{5 ; 5 ; 0.90}=3.45 . \mathrm{F}_{3 ; 3 ; 0.90}=5.39$. 
cohols and fatty acids. So, the use of the lipase extract presented here in the production of flavours could be considered an interesting application.

The concentrated extracts presented a good thermal stability, and are more stable than the crude enzymes. The $\mathrm{CC}$ and $\mathrm{CP}$ enzymes presented higher activities at $\mathrm{pH}$ memories around neutrality $(6.5)$ and $40{ }^{\circ} \mathrm{C}$. On the other hand, the IC and IP enzymes kept the activity in a wide range of memories of $\mathrm{pH}$.

Preliminary studies of application of the produced lipase showed promising results. The enzymatic production of geranyl propionate using geraniol and propionic acid as substrates in solvent-free system yielded a reaction conversion of $42 \pm 1.5 \%$

\section{Acknowledgments}

The authors thank CAPES and CNPq for the financial support of this work and scholarships.

\section{References}

Abbas H, Comeau L (2003) Aroma synthesis by immobilized lipase from Mucor sp. Enz Microb Technol 32:589-595.

Bapiraju KVVSN, Sujatha P, Ellaiah P, Ramana T (2005) Sequential parametric optimization of lipase production by a mutant strain Rhizopus sp. BTNT-2. J Basic Microbiol 45:257-273.

Bon EPS, Ferrara MA, Corvo ML (2008) Enzimas em biotecnologia. Interciência, Brazil.

Bradoo S, Rathi P, Saxena RK, Gupta R (2002) Microwaveassisted rapid characterization of lipase selectivities. J Biochem 51:115-120.

Colen G, Junqueira RG, Moraes-Santos T (2006) Isolation and screening of alkaline lipase-producing fungi from Brazilian savanna soil. World J Microbiol Biotechnol 22:881-885.

Fernandes MLM, Krieger N, Baron AM, Zamora PP, Ramos LP, Mitchell DA (2004) Hydrolysis and synthesis reactions catalysed by Thermomyces lanuginosa lipase in the AOT/Isooctane reversed micellar system. J Mol Catal B Enzymatic 30:43-49.

Ghandi N, Sawant SB, Joshi JB (1995) Specificity of a Lipase in Ester Synthesis: Effect of Alcohol. Biotechnol Progress 11:282-287.

Griebler N, Polloni A, Remonatto D, Arbter F, Vardanega R, Cechet J, Di Luccio M, Oliveira D, Treichel H, Cansian R, Rigo E, Ninow J (2011) Isolation and Screening of LipaseProducing Fungi with Hydrolytic Activity. Food Bioproc Technol 4:578-586.

Gutarra MLE, Godoy MG, Maugeri F, Rodrigues MI, Freire DMG, Castilho L (2009) Production of an acidic and thermostable lipase of the mesophilic fungus Penicillium simplicissimum by solid state fermentation. Bioresour Technol 100:5249-5254.

Hasan F, Shah AA, Hameed A (2006) Industrial applications of microbial lipases. Enzyme Microb Technol 39:235-251.

Immanuel G, Esakkiraj P, Jebadhas A, Iyapparaj P, Palavesam A (2008) Investigation of lipase production by milk isolate Serratia rubidaea. Food Technol Biotechnol 46:60-65.
Juaréz MD, Osawa CB, Acuña ME, Sammán N, Gonçalves LAG (2011) Degradation in soybean oil, sunflower oil and partially hydrogenated fats after food frying, monitored by conventional and unconventional. Food Control 22:1920-1927.

Kademi A, Leblane D, Houde A (2004) Lipases. In: Pandey A. Concise Encyclopedia of Bioresource Technology. The Haworth Press Inc., New York.

Kashmiri MA, Adnan A, Butt BW (2006) Production, purification and partial characterization of lipase from Trichoderma viride. African J Biotechnol 5:878-882.

Langrand G, Triantaphylides C, Baratti J (1998) Lipase catalyzed formation of flavour esters. Biotechnol Lett 10:549-554.

Lotti M, Alberghina L (2007) Lipases: Molecular Structure and Functions. In: Polaina J and MacCabe A P. Industrial Enzymes: Structure, Function and Applications. Springer, Dordrecht, pp 263-282.

Martins VG, Kalil SJ, Costa JV (2008) Co-produção de lipase e biossurfactante em estado sólido para utilização em biorremediação de óleos vegetais e hidrocarmonetos. Química Nova 31:1942-1947.

Menoncin S, Domingues NM, Freire DMG, Toniazzo G, Cansian RL, Oliveira JV, Di Luccio M, Oliveira D, Treichel H (2010) Study of the Extraction, Concentration, and Partial Characterization of Lipases Obtained from Penicillium verrucosum using Solid-State Fermentation of Soybean Bran. Food Bioproc Technol 3:537-544.

Peter F, Preda G (2002) Characterisation of pancreatic lipase substrate specificity in organic reaction media by a kinetic method. J Mol Catal B Enzymatic 19-20:467-472.

Pinheiro TF, Menoncin S, Domingues NM, Oliveira D, Treichel H, Di Luccio M, Freire DM (2008) Production and partial characterization of lipase from Penicillium verrucosum obtained by submerged fermentation of conventional and industrial media. Ciência e Tecnologia de Alimentos 28:444450.

Reis P, Holmberg K, Watzke H, Leser ME, Miller R (2009) Lipases at interfaces: a review. Adv Colloid Interface Sci 147-148:237-250.

Sharma R, Chisti Y, Banerjee UC (2001) Production, purification, characterization, and applications of lipases. Biotechnol Adv 19:627-662.

Shu C-H, Xu C-J, Lin G-C (2006) Purification and partial characterization of a lipase from Antrodia cinnamomea. Process Biochem 41:734-738.

Smaniotto A, Skovronski A, Rigo E, Tsai SM, Durrer A, Foltran LL, Di Luccio M, Oliveira JV, Oliveira D, Treichel H (2012) 'Synthetic lipase' production from a newly isolated Sporidiobolus pararoseus strain by submerged fermentation. Braz J Microbiol 40:1490-1498.

Stanbury PF, Whitaker A, Hall SJ (2003) Principles of fermentation technology. Butterworth-Heinemann, London.

Sun SY, Xu Y (2008) Solid-state fermentation for 'whole-cell synthetic lipase' production from Rhizopus chinensis and identification of the functional enzyme. Process Biochem 43:219-224.

Sun SY, Xu Y, Wang D (2009) Novel minor lipase from Rhizopus chinensis during solid state fermentation: Biochemical characterization and its esterification potential for ester synthesis. Bioresour Technol 100:2607-2612.

Teng Y, Xu Y (2008) Culture condition improvement for wholecell lipase production in submerged fermentation by 
Rhizopus chinensis using statistical method. Bioresour Technol 99:3900-3907.

Treichel H, Oliveira D, Mazutti MA, Di Luccio M, Oliveira JV (2010) A review on microbial lipases production. Food Bioproc Technol 3:182-196.

Wang D, Xu Y, Shan T (2008) Effects of oils and oil-related substrates on the synthetic activity of membrane-bound lipase from Rhizopus chinensis and optimization of the lipase fermentation media. Biochem Eng J 41:30-37.

Wang Y, Srivastava KC, Shen GJ, Wang HY (1995) Thermostable alkaline lipase from a newly isolated thermophilic Bacillus, strain A30-1 (ATCC 53841). J Ferment Bioeng 79:433-438.

All the content of the journal, except where otherwise noted, is licensed under a Creative Commons License CC BY-NC. 